\title{
腎細胞癌の予後
}

\author{
千葉大学医学部泌尿器科学教室 畺田壽 彦
(主任: 自崎渟教授)
}

\section{PROGNOSIS IN 104 PATIENTS WITH RENAL CELL CARCINOMA}

Toshihiko Sanada

From the Department of Urology, School of Medicine, Chiba University, Chiba

(Director: Prof. J. Shimazaki)

The clinical, pathologic and survival data were analyzed for 104 patients with renal cell carcinoma treated by nephrectomy with or without adjuvant therapy. Factors influencing prognosis were evaluated.

The patients could be regarded as "fully cured" after 5 years of follow-up, at which time the survival was the same as the survival for a normal population. The prognostic values of individual parameters were evaluated in comparing the "fully cured" patients with the others.

The staging was a most important factor which influenced prognosis. The invasion of the renal vein, hematuria alone, weight of the renal tumor mass, and invasion of the renal pelvis, were also correlated well with prognosis but were of lesser importance than the staging.

要旨：1）千葉大学医学部泌尿器科拈よび $2 つ の$ 関連病院に括いて, 腎剔出術を施行した腎細胞癌症例104例 を集計し, その臨床像, 臨床病理学的所見および治療法等につき, 検討を加兄, これら各要因と予後との関連 性につき解析した。

2）期待生存率と累積生存率とを比較検討した結果, 治癒判定時期は, 単密には, 術後15年以上, 推計学的 には術後 5 年, と考兄られた。

3）累積生存率，相対生存率，および， 5 年以内死亡例と 5 年以上生存例の比較検討等において，予後と最 も良く関連性を示した要因は，病期分類であつた。 その他の因子で，いずれかの検討方法により，比較的良く 関連性を示した要因は，静脈内腫瘍栓塞，腎孟内侵潤，血尿のみ，腎重量，発熱，および，赤沈値等であつ た.

4）治療法と予後については，病期分類別に検討したが，関連性をみとめなかつた。しかし，何らかの補助 療法を併用した方が，治療成績は良好であつた．また，経腹腔式腎剔出術，抢よび，ホルモン療法の併用等の 治療成績が優れている傾向を示したが，近年の術後管理の発展が影響を与えた結果とも考えられた。

\section{はじめに}

腎細胞癌の予後決定因子として, 組織学的悪性度や病 期のほかに，赤沈值や血清蛋白異常が示唆されている. 今回，腎細胞癌につき，治癒判定時期を検討し，さら に, 臨床像, 臨床病理学的所見, および, 治療法等と予 後の関連性について検討した結果を報告する.

\section{対象および方法}

昭和 35 年 7 月, 教室開設以来, 昭和 52 年末までに千葉 大学泌尿器科沶よび 2 つ関連病院にて, 腎剔出術施行 した104例を集計した。
観察期間は, 最短 7 カ月, 最長 16 年10カ月であつた.

1. 生存率曲線の検討は, 栗原ら 1 により紹介された 計算法に従つた。累積生存率（実測生存率之同じ）の推 計学的検㣙は Greenwood $^{2}$ の式に従つた. 累積生存率 の検討に扮いて有意差を認めた因子につき，さらに相対 生存率に㨟ける推計学的検討を加えた. 期待生存率は厚 生省の指標に揭載された各年次の簡易生命表 ${ }^{3 / 4)}$ を用い て, 累積算出した.

2. 治瘾判定時期の推定は, 期待生存率および累積生 存率を片対数表にプロットして，これら 2 つ生存率曲 
線が平行になる時期をもつて, 決定した ${ }^{55}$.

3. 検討した因子の内訳は，以下の通りである．年 龄, 性, 初発症状発現から来院までの期間, 主訴抢よび 症状, 発熱, 赤沈值，および，貧血等の患者側因子．患 側, 腎重量, 腫瘍の大きさ, 腫瘍被膜, 腎盂内侵潤, 静 脈内腫瘍栓塞, リンパ節転移, 病期分類 ${ }^{6}$, 細胞の配列 型, 細胞型, 出血巣, および, 壊死巣等の腫瘍側因子. これらを, 表 1 , 表 2 , 扣よび，表 3 の如く細分類し た.

4. 細胞の配列型 および 細胞型等の 細分類について は，2つ以上の組織像が共存あるいは混在する場合に は，その占める割合の優勢なものをもつて決定した.

5. 手術術式は腰部斜切開, 旁腹直筋切開, あるいは, 経腹腔式腎剔出術. 手術と併用した補助療法の内訳は以 下の通りである，放射線療法は，原則として，術後腎門 部にテレコバルト前後 2 門照射を行い, 平均照射野は, 綐 $9.8 \mathrm{~cm}(7 \sim 14 \mathrm{~cm})$, 横 $8.1 \mathrm{~cm}(7 \sim 15 \mathrm{~cm})$, 照射量は 1 日各 $200 \sim 300 \mathrm{rad}$ で, 合計腫瘍線量 1,060 6,900 rad, 平均 5,129rad. 化学療法は, マイトマイシンC 合計6 $80 \mathrm{mg}$ を中心に, トョマイシン合計 $10 \sim 22.5 \mathrm{mg}, 5-\mathrm{FU}$ 合計 $7,500 \mathrm{mg}$ ，マーフィリン等が経口的あるいは経静脈 的に，種々の組み合わせで投与された。 ホルモン療法 は，酶酸メドロキシプロゲステロン，あるいは，酶酸ク ロルマジノンが 1 日量 $100 \mathrm{mg}$, 最短 2 力月, 最長 39 力月 間，経口的に継続投与された。

\section{結果}

1. 全104例 の年齢別, 性別構成を図 1 亿示した。男 子69例, 女子 35 例, 男女比は 2 対 1 . 年秢は, 最年少 15 歳, 最高路76歳, 平均 $56.1 \pm 11.7$ 藏, その構成は, 男子 28 76歳 (平均 56.9 歳), 女子 $15 \sim 76$ 歳 (平均 54.5 歳), 全体として60歳代にピークを示したが，男子は60歳代の みに，女子は60歳代および30歳代に二峰性のピークを示 した. 40 歳以下 9 例中 7 例（78\%）は女子で, 若年女子 好発傾向をみとめた。患側は, 右51例, 左53例, 差をみ とめない。

2. 全104例の期待生存率, 累積生存率, および, 相対 生存率を図 2 に示した. $1 ， 3 ， 5 ， 8 ， お よ ひ ゙ 10$ 年の 各生存率は以下の通りであつた。期待生存率は，おのお の，98.2，94.7，90.9，84.5，扩よび79.4\%. 累積生存

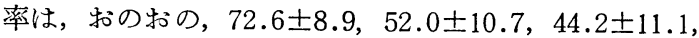
$36.5 \pm 12.3$ ，および， $32.8 \pm 13.1 \%$. 相対生存率は，お

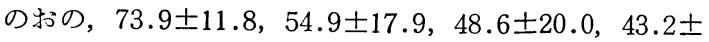
21.9 , 拈よび, $41.3 \pm 22.3 \%$.これらは, 腎㙉癌との重
図 1。腎細胞癌手術例 104例の年令別・性別構成

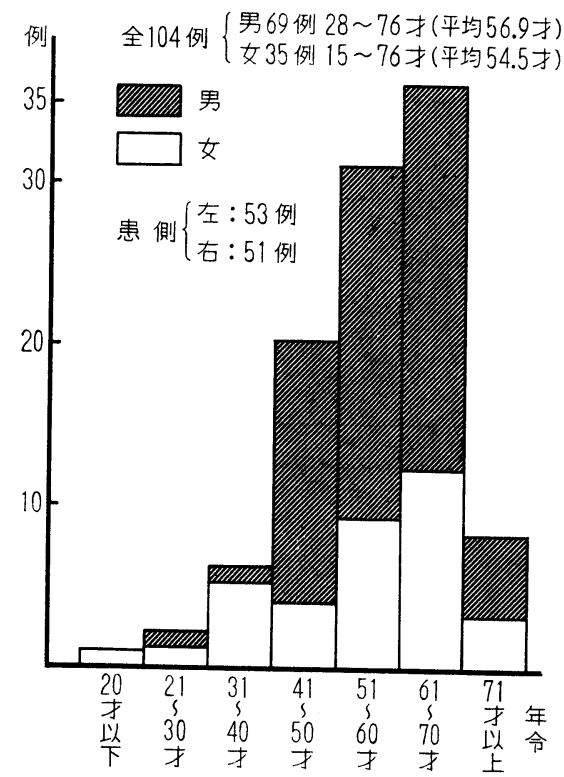

図 2。腎細胞癌手術例 104例の生存率

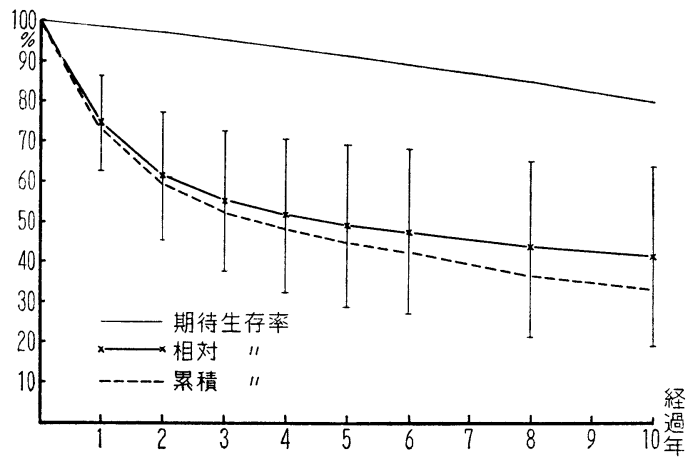

複癌 2 例, 術後 1 力月以内の手術死 7 例 $(6.7 \%)$, 打よ び，追跡不能 3 例 $(2.9 \%$ )を含んだ検討結果である.

3. 戸籍に基づく死因調查を, 追跡不能 3 例を除く 101例中死亡56例 $(55.4 \%)$ につき実施した．その結果， 癌死37例 (66.1\%), 他因死17例 (30.4\%), 拉よび，不 明 2 例 $(3.6 \%)$ であった. 5 年以上生存例 24 例 (23.8 $\%), 5$ 年以後死亡例 7 例 $(6.9 \%)$, この 7 例 の 死因の 内訳は, 癌死 4 例, および, 他因死 3 例であつた. 5 年 以後癌死 4 例の病期は, Stage IV, III, II, 各 1 例 と病 期分類不能の 1 例であつた. Stage IV (肺転移)，未分 化細胞, 充実型の 1 例は, 放射線 +化学療法併用して術 後 5 年 9 カ月で死亡. Stage III, 顆粒細胞，充実型の 1 
図 3. 腎細胞癌手術例 104例の累積生存率と期待生 存率の比較

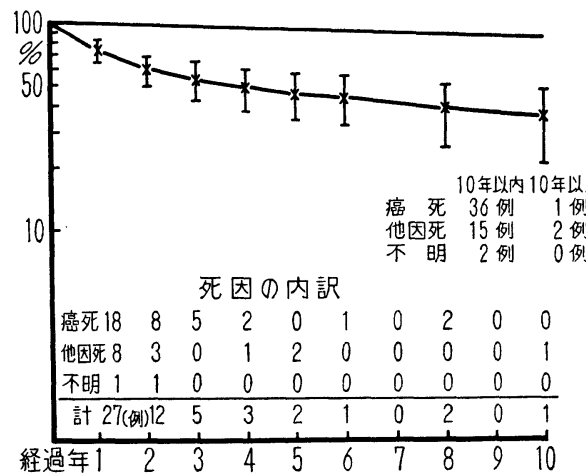

例は, 放射線療法単独併用して術後 8 年 8 カ月で死亡. Stage II , 淡明細胞, 乳頭状の 1 例は, 放射線療法単独 併用して術後 7 年10力月で死亡.

治癒判定時期の推定結果（図 3, 図 4) は全症例の検 討（図 3 ）で術後 5 年をすぎて平行に近くなつている が，5年以上生存 24 例の検討 (図 4) では術後15年経過 しても平行とならない. 従つて, 治癒判定時期は術後 15
図 4. 腎細胞癌手術例 5 年以上生存例 24 例の累積生 存率之期待生存率の比較

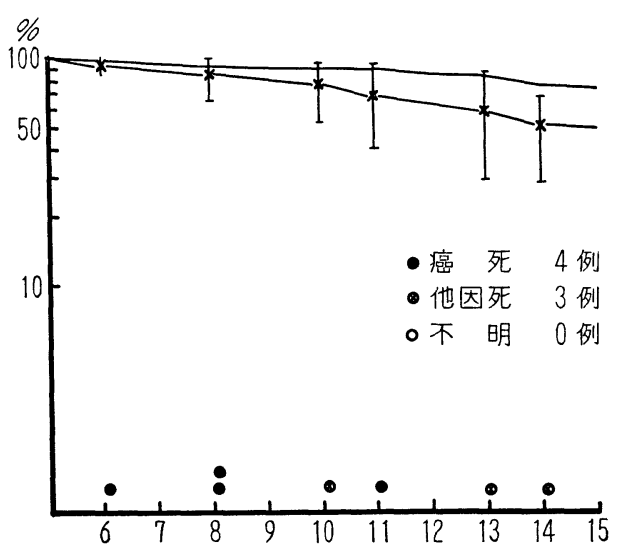

年以上と推定された. しかし，図4 亿示す如く，期待生 存率曲線は累積生存率の誤差範囲内にあり, 術後 5 年を 経過すれば, 再発の危険はあるものの, 一応, 治癒と判 定して良いと考学られた。

4. 検討した患者側因子の内訳は，表 1 の通りであ

表 1. 患者側因子と予後

\begin{tabular}{|c|c|c|c|c|c|c|}
\hline & & 例数 $(\%)$ & 1 年生存率 & 3 年生存率 & 5 年生存率 & 10年生存率 \\
\hline 症 & 例 & 104 & $72.6 \pm 8.9$ & $52.0 \pm 10.7$ & $44.2 \pm 11.1$ & $32.8 \pm 13.1$ \\
\hline \multirow{2}{*}{ 年 令 } & 50 才以下 & $29(27.9)$ & $70.9 \pm 17.3$ & $49.1 \pm 20.4$ & $42.5 \pm 21.4$ & $28.5 \pm 27.2$ \\
\hline & 51才以上 & $75(72.1)$ & $73.3 \pm 10.5$ & $46.8 \pm 11.0$ & $35.4 \pm 10.2$ & $27.8 \pm 11.2$ \\
\hline \multirow{2}{*}{ 性 } & 女 & $35(33.7)$ & $76.1 \pm 14.7$ & $54.9 \pm 18.7$ & $44.5 \pm 19.9$ & $23.1 \pm 24.4$ \\
\hline & 男 & $69(66.3)$ & $70.8 \pm 11.3$ & $50.6 \pm 13.1$ & $44.3 \pm 13.4$ & $37.3 \pm 14.5$ \\
\hline \multirow{2}{*}{ ネ初発から来院までの期間 } & 1 力月以内 & $46(44.2)$ & $79.5 \pm 6.1$ & $63.6 \pm 7.6$ & $51.5 \pm 8.9$ & $44.6 \pm 9.9$ \\
\hline & 1 カ月を越えるすの & $58(55.8)$ & $66.9 \pm 6.4$ & $42.8 \pm 7.1$ & $37.9 \pm 7.1$ & $26.3 \pm 7.6$ \\
\hline \multirow{5}{*}{ 主訴および症状 } & 血尿のみ & $28(26.9)$ & $85.7 \pm 13.2$ & $74.3 \pm 16.7$ & $69.9 \pm 17.9$ & $49.0 \pm 24.0$ \\
\hline & 腎腫瘤 & $25(24.0)$ & $67.4 \pm 18.9$ & $49.3 \pm 20.8$ & $37.1 \pm 21.8$ & $12.4 \pm 29.4$ \\
\hline & 血尿のないもの & $20(19.2)$ & $64.1 \pm 21.7$ & $46.3 \pm 23.6$ & $36.0 \pm 25.8$ & $12.0 \pm 29.0$ \\
\hline & 腎部疼痛 & $31(29.8)$ & $57.4 \pm 17.9$ & $37.1 \pm 17.6$ & $27.7 \pm 15.8$ & $27.7 \pm 15.8$ \\
\hline & 食思不振るいそう等 & $18(17.3)$ & $69.7 \pm 22.6$ & $27.9 \pm 23.4$ & $27.9 \pm 23.4$ & $18.6 \pm 21.8$ \\
\hline \multirow{2}{*}{ 太発 熱 2 迥以上 $37.1^{\circ} \mathrm{C}$ 以上） } & 無 & $78(75.0)$ & $78.4 \pm 4.8$ & $58.9 \pm 6.1$ & $52.5 \pm 6.5$ & $35.4 \pm 8.6$ \\
\hline & 有 & $26(25.0)$ & $55.1 \pm 10.1$ & $30.8 \pm 9.9$ & $20.5 \pm 8.9$ & $20.5 \pm 8.9$ \\
\hline \multirow{2}{*}{ 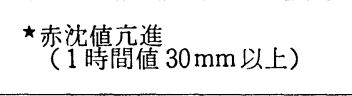 } & 無 & $41(43.2)$ & $84.4 \pm 10.9$ & $71.5 \pm 15.5$ & $61.9 \pm 18.5$ & $61.9 \pm 18.5$ \\
\hline & 有 & $54(56.8)$ & $64.7 \pm 13.4$ & $36.7 \pm 14.4$ & $29.2 \pm 14.1$ & $22.5 \pm 13.7$ \\
\hline \multirow{2}{*}{ (Hb12盆/dl Sahli 70\%以下) } & 無 & $74(72.5)$ & $78.1 \pm 10.0$ & $54.4 \pm 13.1$ & $49.6 \pm 13.6$ & $32.2 \pm 17.2$ \\
\hline & 有 & $28(27.5)$ & $60.7 \pm 18.5$ & $46.2 \pm 18.9$ & $33.0 \pm 18.7$ & $33.0 \pm 18.7$ \\
\hline
\end{tabular}

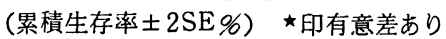


図 5, 腎細胞癌手術例 104例, 発熱の有無, 相対生 存率

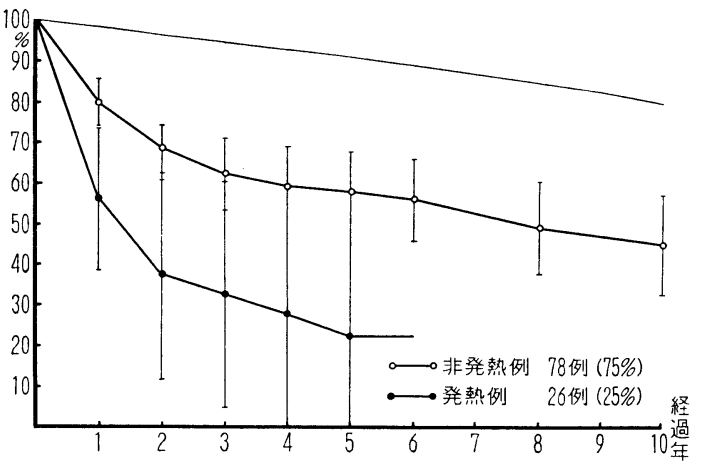

図 6. 腎細胞癌手術例95例の赤沈值別相対生存率

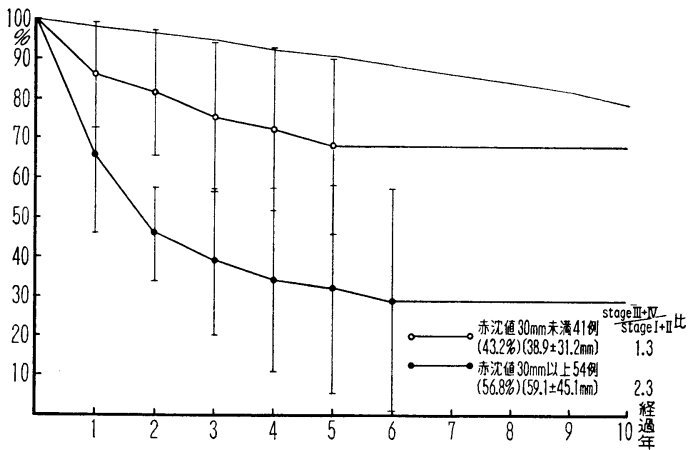

る.これら各因子のうち，予後良好の傾向を示したの は, 50歳以下の若年者群, 女子群, 1 力月以内来院群, 血尿のみを主訴とした群, 発熱のない群, 赤沈值正常 群, および, 貧血のない群等であつた。これら累積生存 率の検討に括いて，推計学的有意差を示した（印）の は, 症状発現より来院までの期間，発熱，および，赤沈 值等の因子であつた.

相対生存率の検討に拈いても, 推計学的有意差を示 したのは, 発熱の術後 1 年 (図 5 ), 赤沈值の術後 2 年 （図 6）であつた. 赤沈值実測值の推計学的検討では, Stage II および Stage IIIの 2 群間で危険率 $5 \%$ 以下の, また，低進展度群（Stage I + II）および高進展度群 (Stage III +IV) の 2 群間で危険率 $1 \%$ 以下の有意差を 示した. しかし，分割表による赤沈值と病期の関連性の 検討では，有意差を認めない（表 4 ），従つて，発熱お よび赤沈值の 2 要因は, 早期予後を予測する, 比較的適 当な指標に留まると考えられた。

5. 検討した腫瘍側因子の内訳は表 2 の通りである.
図 7. 腎細胞癌手術例, 腫瘍被膜の有無, 累積生 存率

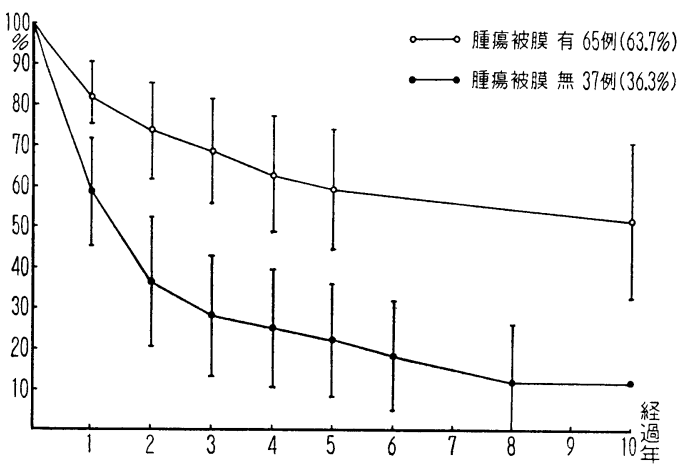

因 8. 腎細胞癌手術例静脈内腫瘳栓塞の有無累積 生存率

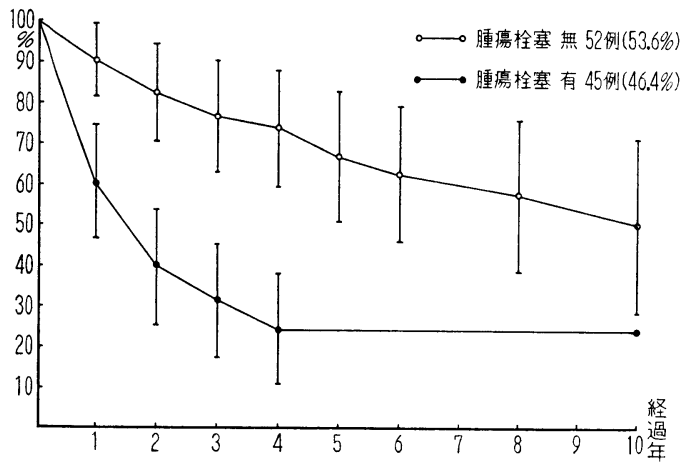

図 9.腎細胞癌手術例 103例の病期分類別相対 生存率

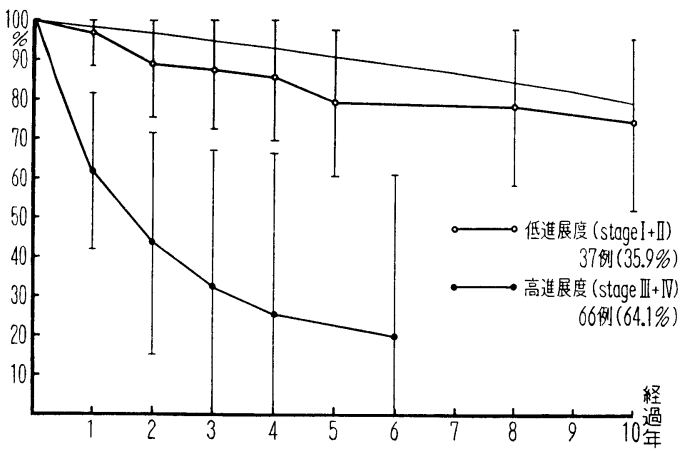

対象は, 病期分類不能 1 例を除く103例を原則とした。 初診時遠隔転移をみとめた Stage IV19例の転移部位は, 肺16例, 腰椎 2 例, 胸椎 1 例, および, 大腿骨 2 例であ つた.

これら各因子のらち，予後良好の傾向を示したのは， 
表 2. 腫瘍側因子と予後 I

\begin{tabular}{|c|c|c|c|c|c|c|}
\hline & & 例数 (\%) & 1 年生存率 & 3 年生存率 & 5 年生存率 & 10年生存率 \\
\hline 全 & 例 & 104 & $72.6 \pm 8.9$ & $52.0 \pm 10.7$ & $44.2 \pm 11.1$ & $32.8 \pm 13.1$ \\
\hline \multirow{2}{*}{ 患 側 } & 右 & $50(48.5)$ & $69.6 \pm 13.6$ & $56.1 \pm 15.4$ & $44.9 \pm 16.9$ & $39.4 \pm 18.2$ \\
\hline & 左 & $53(51.5)$ & $74.8 \pm 12.1$ & $47.6 \pm 14.8$ & $41 . .9 \pm 15.0$ & $37.6 \pm 15.9$ \\
\hline \multirow{3}{*}{ 腎重量 } & $300 \mathrm{gr}$ 以下 & $30(30.3)$ & $89.8 \pm 11.1$ & $74.5 \pm 16.7$ & $55.7 \pm 18.8$ & $55.7 \pm 18.8$ \\
\hline & $300 \sim 500 \mathrm{gr}$ & $38(38.4)$ & $68.6 \pm 15.7$ & $51.3 \pm 17.8$ & $47.0 \pm 18.3$ & $36.0 \pm 19.1$ \\
\hline & $500 \mathrm{gr}$ 越えるすの & $31(31.3)$ & $65.5 \pm 17.6$ & $33.5 \pm 18.7$ & $23.9 \pm 17.6$ & $14.4 \pm 18.2$ \\
\hline \multirow{2}{*}{$\begin{array}{c}\text { 腫瘍の大きさ } \\
\text { (最大径) }\end{array}$} & $7 \mathrm{~cm}$ 以下 & $46(50.5)$ & $83.9 \pm 11.0$ & $65.1 \pm 15.3$ & $48.9 \pm 18.2$ & $29.4 \pm 24.1$ \\
\hline & $7 \mathrm{~cm}$ 越えるもの & $45(49.5)$ & $64.0 \pm 14.4$ & $40.3 \pm 14.9$ & $37.9 \pm 14.9$ & $31.2 \pm 15.0$ \\
\hline \multirow{2}{*}{ 太腫瑒被膜* } & 無 & $37(36.3)$ & $58.9 \pm 16.3$ & $28.1 \pm 15.0$ & $22.4 \pm 13.9$ & $12.5 \pm 13.6$ \\
\hline & 有 & $65(63.7)$ & $81.7 \pm 9.9$ & $68.7 \pm 12.9$ & $59.5 \pm 14.9$ & $52.1 \pm 19.1$ \\
\hline \multirow{2}{*}{ 腎而内侵潤 * } & 無 & $39(38.2)$ & $78.7 \pm 13.4$ & $66.4 \pm 15.9$ & $58.5 \pm 17.6$ & $50.1 \pm 21.0$ \\
\hline & 有 & $63(61.8)$ & $69.5 \pm 11.9$ & $42.1 \pm 14.0$ & $33.9 \pm 14.1$ & $23.3 \pm 16.3$ \\
\hline \multirow{2}{*}{ 太静脈内腫瘍栓寨＊ } & 無 & $45(50.0)$ & $90.6 \pm 8.9$ & $77.0 \pm 13.6$ & $67.3 \pm 15.9$ & $50.4 \pm 21.3$ \\
\hline & 有 & $45(50.0)$ & $60.8 \pm 14.0$ & $31.6 \pm 14.3$ & $24.2 \pm 14.3$ & $24.2 \pm 14.3$ \\
\hline \multirow{2}{*}{ ネリンパ節転移** } & 無 & $85(83.3)$ & $76.5 \pm 9.4$ & $58.8 \pm 11.6$ & $50.9 \pm 12.4$ & $39.6 \pm 15.5$ \\
\hline & 有 & $17(16.7)$ & $57.6 \pm 24.3$ & $22.4 \pm 22.0$ & $14.9 \pm 19.1$ & $7.5 \pm 14.3$ \\
\hline \multirow{4}{*}{$\star$ Stage 分類 $* * *$} & I & $7(6.8)$ & 100.0 & $86.0 \pm 26.2$ & $86.0 \pm 26.2$ & $67.0 \pm 39.3$ \\
\hline & II & $30(29.1)$ & $93.0 \pm 9.4$ & $81.7 \pm 14.8$ & $67.8 \pm 18.1$ & $58.8 \pm 23.6$ \\
\hline & III & $47(45.6)$ & $72.0 \pm 13.6$ & $36.2 \pm 17.2$ & $26.4 \pm 11.7$ & $26.4 \pm 11.7$ \\
\hline & IV & $19(18.5)$ & $30.0 \pm 21.4$ & $16.0 \pm 18.7$ & $16.0 \pm 18.7$ & 0 \\
\hline
\end{tabular}

*即: 剔出標本肉眼的所見, **印: 手術時腎茎部リンパ節, ***印 : 文献 (4)

Stage I : 腎線維被膜内に限局するすの Stage II : 周囲脂肪組織におよぶが

Gerota膜をとえないあの Stage III : 堅静脈, 督周用組織, 所属リンパ節に

およぶあの StageIV : 隣接蔵器におよぶあの, あるいは, 遠隔転移のあるあの

(累積生存率土2SE\%) 太旷有意差あり

表 3 . 腫瘍側因子と予後 II（顕微鏡的所見）

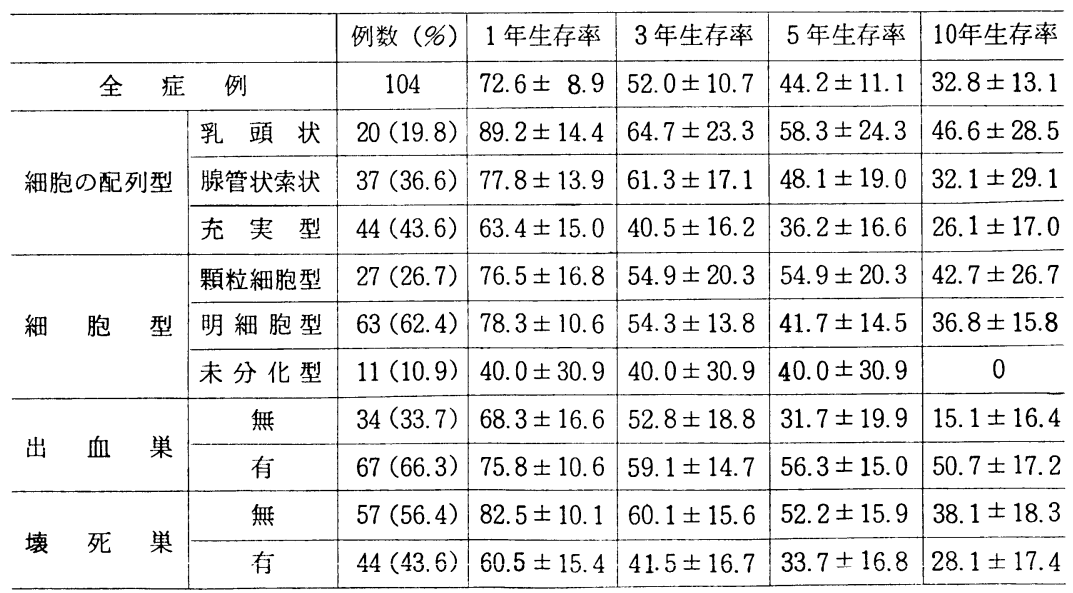

（累積生存率土2SE\%） 
表 4 . 赤沈 1 時間値の検討

\begin{tabular}{r|r|r|r|c}
\hline & $\mathrm{n}$ & $\max$ & $\min$ & mean \pm S. D. \\
\hline Stage I & 7 & 74 & 10 & $49.0 \pm 25.0$ \\
\hline II & 27 & 135 & 6 & $36.4 \pm 32.6^{*}$ \\
\hline III & 45 & 155 & 2 & $55.8 \pm 45.7$ \\
\hline IV & 16 & 140 & 6 & $68.1 \pm 44.0$ \\
\hline
\end{tabular}

* $\mathrm{p}<0.05$

\begin{tabular}{r|c|c|c}
\hline & $30 \mathrm{~mm}$ 以上 & $30 \mathrm{~mm}$ 未満 & \\
\hline Stage I & 5 & 2 & 7 \\
\hline II & 11 & 16 & 27 \\
\hline III & 26 & 19 & 45 \\
\hline IV & 12 & 4 & 16 \\
\hline & 54 & 41 & 95 例 \\
\hline
\end{tabular}

\begin{tabular}{l|c|c|c|c}
\hline & $\mathrm{n}$ & $\max$ & $\min$ & mean $\pm \mathrm{S} . \mathrm{D}$. \\
\hline Stage I + II & 34 & 135 & 6 & $38.9 \pm 31.2^{* *}$ \\
\hline Stage III + IV & 61 & 155 & 2 & $59.1 \pm 45.1$ \\
\hline
\end{tabular}

* $\mathrm{p}<0.01$

\begin{tabular}{l|c|c|c}
\hline & $30 \mathrm{~mm}$ 以上 & $30 \mathrm{~mm}$ 未満 & \\
\hline Stage I + II & 16 & 18 & 34 \\
\hline Stage III + IV & 38 & 23 & 61 \\
\hline & 54 & 41 & 95 例 \\
\hline
\end{tabular}

表 5 . 治療法と予後

\begin{tabular}{|c|c|c|c|c|c|}
\hline & 例数 $(\%)$ & 1 年生存率 & 3 年生存率 & 5 年生存率 & 10年生存率 \\
\hline 症 & 104 & $72.6 \pm 8.9$ & $52.0 \pm 10.7$ & $44.2 \pm 11.1$ & $32.8 \pm 13.1$ \\
\hline 手術のみ & $20(19.4)$ & $40.0 \pm 21.9$ & $29.3 \pm 20.6$ & $29.3 \pm 20.6$ & $29.3 \pm 20.6$ \\
\hline 手術十化学療法 & $17(16.5)$ & $75.8 \pm 21.1$ & $61.9 \pm 24.7$ & $48.2 \pm 30.9$ & $32.1 \pm 33.4$ \\
\hline 手術十放射線療法 & $35(34.0)$ & $91.0 \pm 9.9$ & $61.9 \pm 18.4$ & $48.0 \pm 20.2$ & $48.0 \pm 20.2$ \\
\hline 手術十化学・放射線療法 & $31(30.1)$ & $78.2 \pm 15.8$ & $54.1 \pm 21.1$ & $48.7 \pm 21.5$ & $37.1 \pm 21.9$ \\
\hline 低進展度群 & 37 & $94.4 \pm 7.7$ & $82.4 \pm 13.0$ & $72.0 \pm 16.0$ & $58.3 \pm 21.5$ \\
\hline 手術のみ & $5(13.5)$ & $60.0 \pm 43.8$ & $40.0 \pm 43.8$ & $40.0 \pm 43.8$ & $40.0 \pm 43.8$ \\
\hline 手術十化学療法 & $6(16.2)$ & 100 & 100 & $75.0 \pm 43.3$ & $50.0 \pm 50.0$ \\
\hline 手術十放射線療法 & $16(43.2)$ & 100 & $79.7 \pm 20.9$ & $63.4 \pm 26.7$ & $63.4 \pm 26.7$ \\
\hline 手術十化学・放射線療法 & $10(27.1)$ & 100 & 100 & 100 & $85.7 \pm 2^{\prime} 6.5$ \\
\hline 右：放射線単独併用群 & $9(31.0)$ & 100 & $74.0 \pm 31.7$ & $39.5 \pm 40.5$ & $39.5 \pm 40.5$ \\
\hline 放射線単独十放射線 - 化学療法併用 & $12(41.4)$ & 100 & $79.4 \pm 25.9$ & $66.2 \pm 32.5$ & $66.2 \pm 32.5$ \\
\hline 化学療法単独併用十化学療法併用 & $8(27.6)$ & 100 & 100 & $80.0 \pm 35.8$ & $80.0 \pm 35.8$ \\
\hline 左：放射線単独併用群 & $7(24.1)$ & 100 & $85.7 \pm 26.5$ & $85.7 \pm 26.5$ & $85.7 \pm 26.5$ \\
\hline 放射線単独十放射線 - 化学療法併用 & $14(48.3)$ & 100 & $92.3 \pm 14.8$ & $84.6 \pm 20.0$ & $84.6 \pm 20.0$ \\
\hline 化学療法単独併用十化学療法併用 & $8(27.6)$ & 100 & 100 & 100 & $71.4 \pm 34.1$ \\
\hline 高進展度群 & 66 & $60.3 \pm 12.3$ & $30.7 \pm 13.7$ & $23.5 \pm 13.8$ & $17.6 \pm 14.5$ \\
\hline 手術のみ & $15(22.7)$ & $33.3 \pm 24.3$ & $25.9 \pm 22.9$ & $25.9 \pm 22.9$ & $25.9 \pm 22.9$ \\
\hline 手術十化学療法 & $11(16.7)$ & $61.9 \pm 29.9$ & $37.1 \pm 32.3$ & $37.1 \pm 32.3$ & $37.1 \pm 32.3$ \\
\hline 手術十放射線療法 & $19(28.8)$ & $72.2 \pm 21.1$ & $36.4 \pm 25.6$ & $25.9 \pm 25.3$ & $25.9 \pm 25.3$ \\
\hline 手術十化学・放射線療法 & $21(31.8)$ & $67.6 \pm 21.7$ & $25.0 \pm 25.5$ & $12.5 \pm 21.8$ & $12.5 \pm 21.8$ \\
\hline ホルモン剂併用群 & $12(18.2)$ & $80.0 \pm 25.3$ & $48.0 \pm 38.2$ & $48.0 \pm 38.2$ & $45.0 \pm 38.2$ \\
\hline 他の化学療法剂併用群 & $20(30.3)$ & $57.9 \pm 22.7$ & $23.2 \pm 22.1$ & $15.5 \pm 19.4$ & $15.5 \pm 19.4$ \\
\hline 経腹腔式 & $17(25.8)$ & $66.7 \pm 24.3$ & $37.6 \pm 35.9$ & $37.6 \pm 35.9$ & $37.6 \pm 35.9$ \\
\hline 腰部斜切開 & $49(74.2)$ & $57.5 \pm 14.4$ & $28.1 \pm 14.5$ & $21.1 \pm 13.9$ & $15.8 \pm 13.8$ \\
\hline
\end{tabular}

（累積生存率士 2SE\%） 
右側の腫瘍，腎重量 $300 \mathrm{~g}$ 以下の小さいもの，腫瘍の 最大径 $7 \mathrm{~cm}$ 以下のもの, 腫瘍被膜のあるもの, 腎孟内 侵潤のないもの，静脈内腫瘍栓塞のないもの，リンパ節 転移のないもの, および, 低進展度群 (Stage I + II) のもの等であつた（表 2 ). 推計学的有意差を示した (代印) のは, 腫瘍被膜 (図 7 ), 静脈内腫瘍栓塞（図 8), リンパ節転移，および，病期分類等であつた.

相対生存率の検討に括いては, 病期分類のみが, 術後 4 年まで, 推計学的有意差を示した (図 9). 病期分類 は，予後を推測するきわめて有効な指標とい方よう。

6. 検討した病理組織学的因子（湿微鏡的所見）の内 訳は表 3 の通りである.これら各因子のうち，予後良好 の傾向を示したのは, 乳頭状のもの, 顆粒細胞型, 出血 巣のあるもの, 抽゙，壊死巣のないもの等であつた。 これらは, 累積生存率に括いても, あるいは, 相対生存 率においても, 推計学的有意差を認めなかつた。

7. 検討した治療法の内訳は以下の通りである。手術 の文20例 (19.4\%), 手術十化学療法併用群17例 (16.5 $\%)$, 手術十放射線療法併用群35例 $(34.0 \%)$, 特よび, 手術十化学療法十放射線療法併用群31例 (30.1\%) 等で あつた. これらを, 病期別, 患側別, あるいは, 手術法 別に検討した結果を, 表 5 に示した. 補助療法による副 作用は，83例中21例 (25.3\%) にみられ，放射線十化学 療法併用によるもの14例, 放射線単独併用によるもの 6 例，および，化学療法単独併用によるもの 1 例であつ た. 副作用の内訳は, 白血球減少 10 例, 食思不振 7 例, 肝機能障害 3 例，拉よび，貧血 1 例であつた。いずれ も，重篤なものはなく，休止あるいは中止，することに よつて, 正常に復した.

これらの検討結果は, 何らかの補助療法を併用し

図10. 腎細胞癌手術例 103例の治療別累積生存率

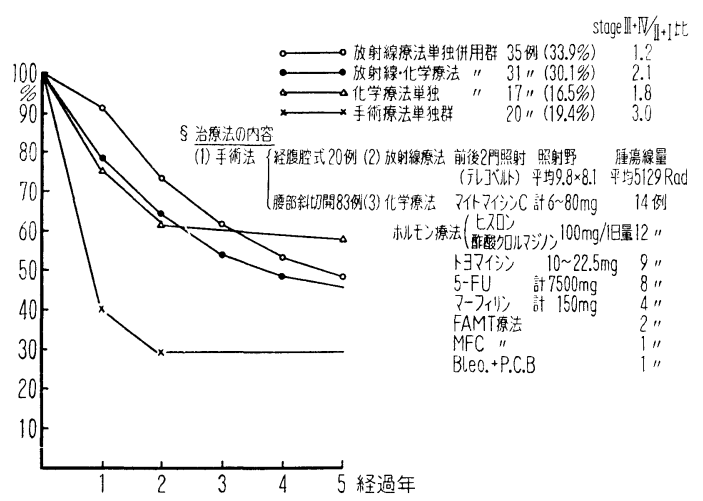

図11，腎細胞癌手術例・低進展度群37例の治療別累 積生存率

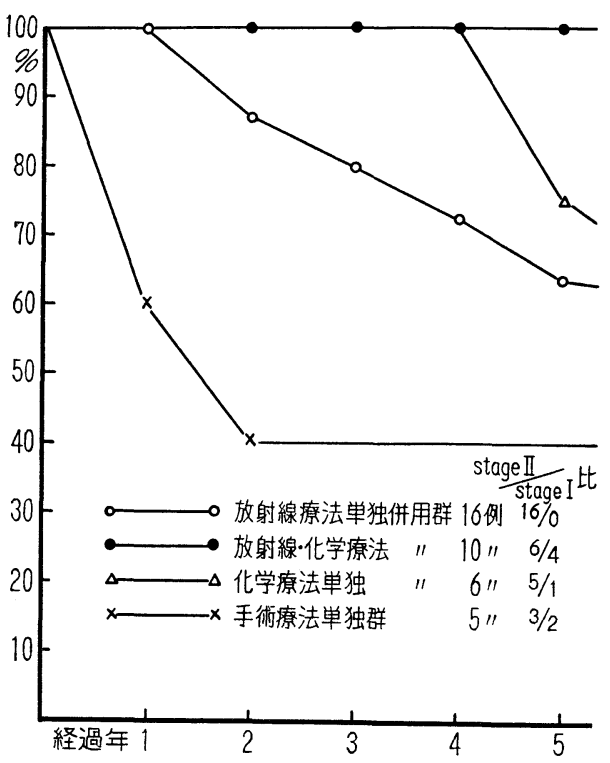

図12。腎細胞癌手術例：高進展度群におけるホルモ ン療法併用群の累積生存率

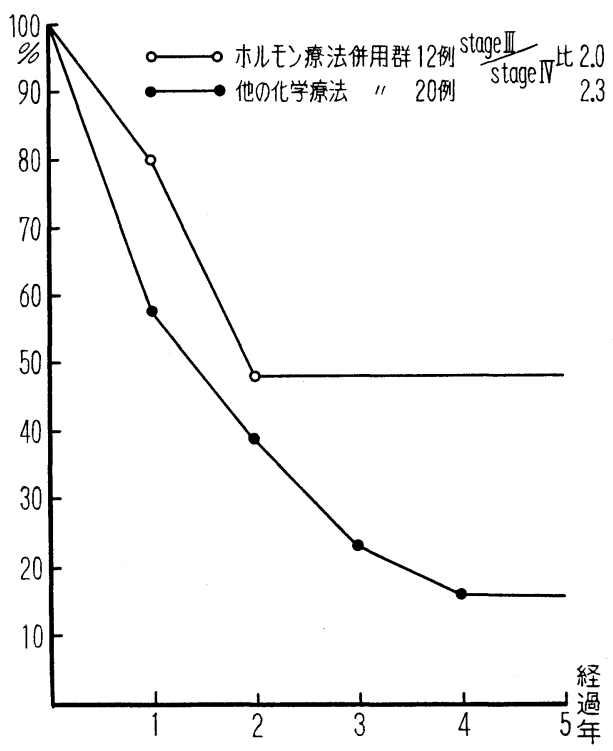

た方が予後良好であつた（図10）。とくに，低進展度群 (Stage I +II) に拈ける検討（図11）でこの傾向は顕著 であり，実際，低進展度群手術のみ施行 5 例中， 2 例癌 死，1例他因死であつたことから，何らかの補助療法を 試みるべきと考えられた。 しかし，症例数が少なく，断 
図13。腎細胞癌手術例：高進展度群における手術術 式・累積生存率

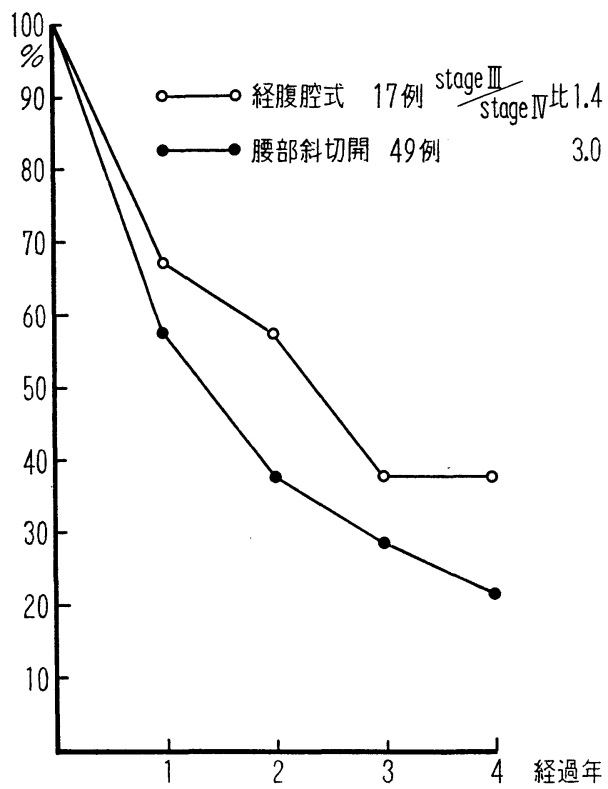

図14。腎細胞癌手術例：低進展度群 - 患側別(左) 治療別累積生存率

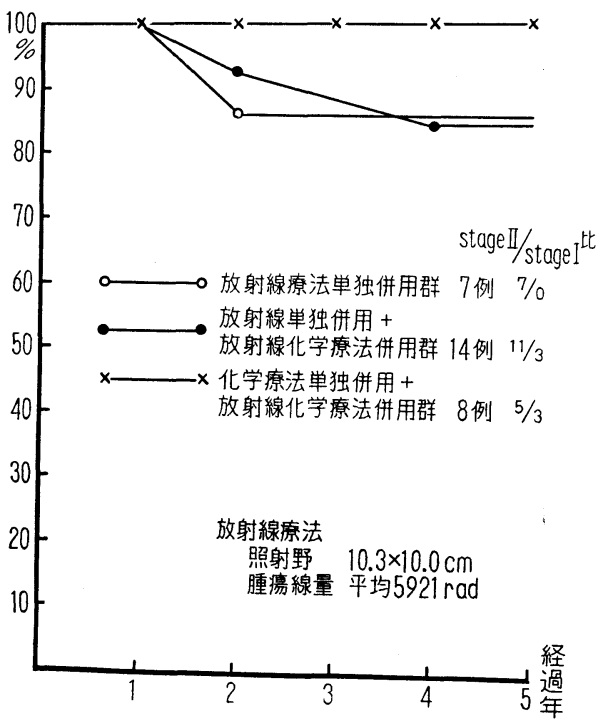

定は差し控えたい。また, 高進展度群 (Stage III +IV) に拉いて，手術法ならびにホルモン剂の効果について検 討した結果，ホルモン剂併用（図12），および，経腹腔 式腎剔出術（図13）は，優れた治療法であると考觉られ た.しかしこれら両治療法は，近年になつて施行され
図15，腎細胞癌手術例：低進展度群・患側別(右) ・ 治療別累積生存率

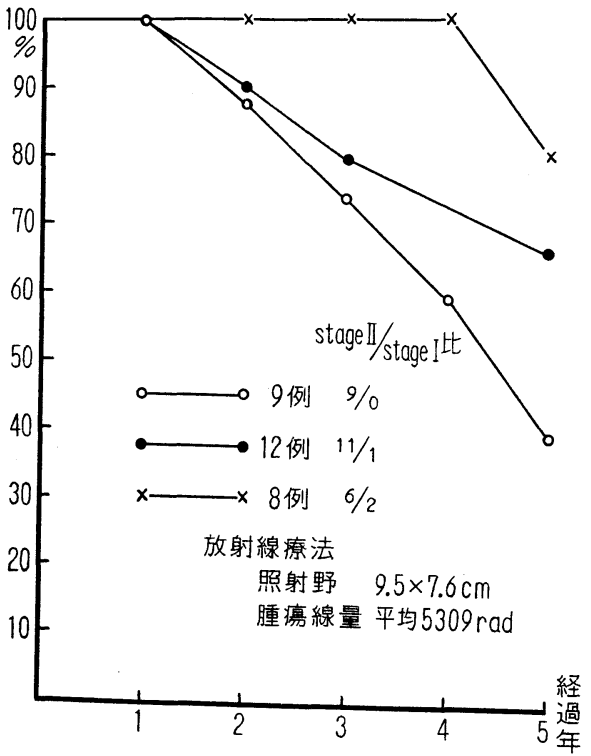

たものが多く，最近の術後管理の進歩が，予後に影響を 与えた可能性もあり，相対生存率による評価が適当と思 われるが，症例数が少なく，検討し得なかつた。

放射線療法の副作用の影響をみるため，低進展度群に 扣ける患側別生存率を検討した。 その結果，右腎腫瘍は 予後不良傾向を示した（図14，15）。しかし，右腎腫瘍 の死亡 3 例の死因は，他因死 2 例（脳出血および沉発性 腹膜炎), 癌死 1 例, これに対し, 左腎腫瘍 の死亡 3 例 の死因は，他因死 1 例 (脳出血)，癌死 1 例，および， 不明 1 例で，死因に沶ける差違は認め難い。また右側 は，照射線量，照射野ともに，有意に小さかつたので， 放射線療法による副作用が予後に影響を与えたとは考え られない。

8. 予後に影響を与えると考えられる諸因子間の関連 性について，検討した結果を表 6 に示した。細胞型と臨 床像（発熱あるいは赤沈值異常）との関連 ${ }^{788)}$ のみなら ず，意外と多くの因子間に和いて，有意な関連性をみ た. 従つて，ある因子が，単一に，直接に，予後に影響 を与劣るのではなく，多数の因子が複合的に予後に影響 を与觉るといえよう。

9. これら予後に影響を与えると考えられる諸要因の らち，最も予後と関連性を認めた因子を表 7 ，表 8 ，に 示した.すなわち，血尿のみを主症状とするもの，低進 展度例等は，予後良好であり，腎静脈内腫瘍栓塞例，腎 
表 6 . 各要因相互の関連性についての検討

\begin{tabular}{|c|c|c|c|c|}
\hline 要 因有意性 & $\mathrm{p}<0.05$ & $\mathrm{p}<0.02$ & $\mathrm{p}<0.01$ & $\mathrm{p}<0.001$ \\
\hline (1) 年令 & & & & \\
\hline (2) 性 & 腎重量 & リンパ節転移 & 腫瘤主訴 & 血尿をみないもの \\
\hline (3) 来院までの期間 & & $\begin{array}{l}\text { 血尿のみ } \\
\text { 血をみいあの }\end{array}$ & 食思不振をみるもの & \\
\hline (4) 血尿のみ & & 来院までの期間 & & \\
\hline (5) 腫瘤を主訴とするもの & 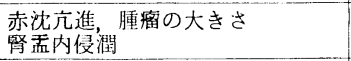 & 腎重量 & 患側 & \\
\hline (6) 顕微鏡的血尿をみないあの & 赤沈亢進, 患側 & & $\begin{array}{l}\text { 婜重量, 細胞型 } \\
\text { 瞫の大きさ }\end{array}$ & 性 \\
\hline (7) 疼痛を主訴とするもの & 腫瘤の大きさ & & 登暬の有無 & \\
\hline (8) 食思不振等をみるもの & & 貧血の有無 & 来院までの期間 & \\
\hline (9) 発熱の有無 & 腎重量 & & 疼痛を主訴とするあの & 赤沈元進 \\
\hline (10) 赤沈值元進の有無 & $\begin{array}{l}\text { リンパ飾転移，血原をみないすの } \\
\text { 細胞の配列型，輣型 }\end{array}$ & & 腫瘍の大きさ & 腎重量, 発熱の有無 \\
\hline (11) 分血の有無 & リンパ節転移，細胞の配列型 & 食思不振等をみるあの & & \\
\hline (12) 患側 & 血尿をみないもの & & 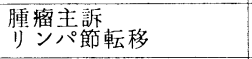 & \\
\hline (13) 腎重量 & $\begin{array}{l}\text { 性, 発熱の有無, 出血策 } \\
\text { 細胞の配列型 }\end{array}$ & 腫瘤主訴 & 血尿をみないあの & 赤沈亢進 \\
\hline (14) 腄瘤の大きさ & 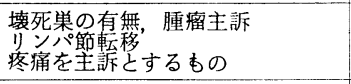 & & 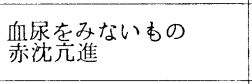 & $\begin{array}{l}\text { 婜重量膜の有無 } \\
\text { 堙 }\end{array}$ \\
\hline (15) 腆演被膜の有無 & & 腎盂内侵潤，静眽侵潤 & $\begin{array}{l}\text { 細胞の配列型 } \\
\text { 将愑を訴とすもの }\end{array}$ & 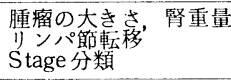 \\
\hline (16) 腎侵㵎の有無 & 腫瘤主訴 & \begin{tabular}{|l} 
紼胞型 \\
腫被膜の有無 \\
\end{tabular} & & 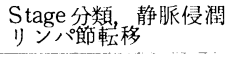 \\
\hline (17) 静脈内侵潤の有無 & リンパ節転移, 細胞の配列型 & 腫瘤被膜の有無 & & Stage 分類，留盉侵睡 \\
\hline (18) リンパ節転移 & $\begin{array}{l}\text { 赤沈傎,腫瘤の大きさ, 分血 } \\
\text { 静脈内侵潤 }\end{array}$ & 性 & Stage 分類，患側 & 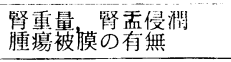 \\
\hline (19) Stage 分類 & & $\begin{array}{l}\text { 細胞型 } \\
\text { 細胞の列型 }\end{array}$ & 腎重量，リンパ節転移 & 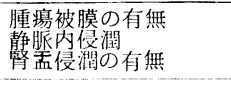 \\
\hline (20) 細胞の配列型 & 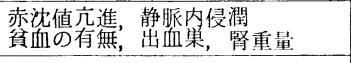 & Stage 分類 & $\begin{array}{l}\text { 細胞型 } \\
\text { 被膜の有無 }\end{array}$ & \\
\hline (21) 細胞型 & 壊死巣，赤沈值穴進 & $\begin{array}{l}\text { 腎孟侵潤 } \\
\text { Stage 分類 }\end{array}$ & $\begin{array}{l}\text { 血尿をみないすの } \\
\text { 綝胞の配列型 }\end{array}$ & \\
\hline (22) 出血巣の有無 & 腎重量, 細胞の配列型 & & & \\
\hline (23) 壊死巣の有無 & 細胞型 & & & \\
\hline
\end{tabular}

盘内侵潤例，腎重量 $500 \mathrm{~g}$ を超えるもの等は予後不良 であるといえよう。また，比較的予後良好と考克られた のは, 腫瘍被膜形成例, 比較的予後不良と考えられたの はリンパ節転移例および発熱例であつた. 5 年以内死亡 例の赤沈值は比較的有意に充進し，また，その腫瘤の大 きさも比較的大きかつたが，これら 2 因子は，予後評価 に適する要因とは考えら机なかつた.

\section{考察}

腎細胞癌の Natural history は，かならずしも明らか ではないが，Riches ${ }^{9)}$ の未治療群81例括よび手術不能例 443例, あるいは, Arner $5^{10)}$ の無治療群35例等の生存 率は，いすれれ，きわめて予後不良といえよう。

一方, 腎細胞癌の発育速度は, 動脈撮影像上 2.5 力
に $0.5 \mathrm{~cm}$ と速いものと共に，大きさの変わらないも の, あるいは，縮小するもの等があるといら ${ }^{11)}$. また， 無治療37年間の観察 ${ }^{12}$ 例や, 腎剔後30年で肺転移をみた 女子例等 ${ }^{13)}$ の報告があり, Doubling time が25〜 600日 であればX線上に観察できるのは20〜30年を要すると ${ }^{14)}$ 指摘されている. さらに, 1928年 Bumps の報告以来, 散発的に報告された自然退縮例は，1977年までに約50例 に達する ${ }^{15)}$. このよらに, 本腫瘍の臨床経過は変幻きわ まりない様相を呈して扣り，予後の推測は，なかなかに 困難である.

このよらな本腫瘍の特殊性を考慮して, 術後 8 年 ${ }^{6)}$, 術後10年，10/16>17)18>无るいは，術後15年 ${ }^{19}$ の予後を評価 しよらとするものもあるが，多くは一般の悪性腫瘍と同 
表 7. 手術施行73例の予後に影響を与えた因子の検討 $I$

( 5 年以内死亡 49 例之 5 年以上生存 24 例の比較, 5 年以内観察例 31 例を除く)

有意差 $+=p<0.1, \quad H=p<0.05, \quad H=p<0.001$

\begin{tabular}{|c|c|c|c|c|c|}
\hline & 例数 $(\%)$ & $\begin{array}{c}5 \text { 年以上死亡 } 49 \text { 例 } \\
(\%)\end{array}$ & $\begin{array}{c}5 \text { 年以上生存 } 24 \text { 例 } \\
(\%)\end{array}$ & 有意差 \\
\hline \multicolumn{2}{|c|}{ 平均年令（73例） } & $57.0 \pm 11.1^{\star}$ & $57.6 \pm 9.8$ & $55.9 \pm 13.6$ & \\
\hline \multicolumn{2}{|c|}{ 年令（50才以下） } & $18(24.7)^{*}$ & $14(28.6)^{* *}$ & $4(16.7)^{* * *}$ & \\
\hline \multicolumn{2}{|l|}{ 性（女） } & $24(32.9)$ & $16(32.7)$ & $8(33.3)$ & \\
\hline \multicolumn{2}{|c|}{ 来院までの期間（1 力月以内） } & $27(36.9)$ & $18(36.7)$ & $9(37.5)$ & \\
\hline \multirow{5}{*}{ 症 状 } & 血尿のみ & $21(28.8)$ & $8(16.3)$ & $13(54.2)$ & HH \\
\hline & 腎 腫 瀷 & $19(26.0)$ & $14(28.6)$ & $5(20.8)$ & \\
\hline & 腎部疼痛 & $28(38.4)$ & $21(42.9)$ & $7(29.2)$ & \\
\hline & 血尿なし & $14(19.2)$ & $11(22.4)$ & $3(12.5)$ & \\
\hline & 食思不振 & $15(20.5)$ & $11(22.4)$ & $4(16.7)$ & + \\
\hline \multicolumn{2}{|l|}{ 有熱例 } & $22(30.1)$ & $18(36.7)$ & $4(16.7)$ & + \\
\hline \multicolumn{2}{|c|}{ 赤沈値 (68例) } & $57.9 \pm 41.7 \star \star$ & $64.8 \pm 43.9$ & $43.6 \pm 33.3$ & \\
\hline \multicolumn{2}{|c|}{ 赤沈穴進例 } & $52(71.2)$ & $37(75.5)$ & $15(62.5)$ & \\
\hline \multicolumn{2}{|l|}{ 貧血例 } & $24(32.9)$ & $18(36.7)$ & $6(25.0)$ & \\
\hline
\end{tabular}

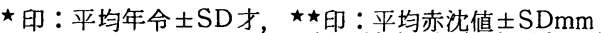

* 印 ( ) 内 73 例中の百分率, ** €ि ( ) 内死亡 49 例中の

百分率，***印（）内生存 24 例中の百分率

表 8 .手術施行73例の予後に影響を与えた因子の検討 II

( 5 年以内死亡 49 例と 5 年以上生存 24 例の比較, 5 年以内観察例 31 例を除く)

\begin{tabular}{|c|c|c|c|c|}
\hline & 例数 (\%) & $\begin{array}{c}5 \text { 年以内死亡49例 } \\
(\%)\end{array}$ & $\begin{array}{c}5 \text { 年以上生存 } 24 \text { 例 } \\
(\%)\end{array}$ & 有意差 \\
\hline 患側 & $32(43.8)^{*}$ & $22(44.9)^{* *}$ & $10(41.7)^{* * *}$ & \\
\hline 平均腎重量（69 例） & $481.2 \pm 301.3 \star$ & $536.5 \pm 333.4$ & $370.4 \pm 184.2$ & + \\
\hline 腎重量（500gr超えるもの） & $27(36.9)$ & $22(44.9)$ & $5(20.8)$ & H \\
\hline $\begin{array}{c}\text { 腫瘤の大きさ (平均最大径) } \\
\text { (68例) }\end{array}$ & $9.4 \pm 4.2 \star \star$ & $10.1 \pm 4.5$ & $8.0 \pm 3.3$ & + \\
\hline 腫瘤の大きさ（7cm以下） & $26(35.6)$ & $18(36.7)$ & $8(33.3)$ & \\
\hline 腫䗵の大きさ（5cm以下） & $11(15.1)$ & $6(12.2)$ & $5(20.8)$ & \\
\hline 腫瑒被膜形成例 & $35(47.9)$ & $20(40.8)$ & $15(62.5)$ & + \\
\hline 腎孟内侵潤例 & $44(60.3)$ & $34(69.4)$ & $10(41.7)$ & $H$ \\
\hline 静脈内侵潤例 & $38(52.1)$ & $33(67.3)$ & $5(20.8)$ & HI \\
\hline リンパ節転移例 & $15(20.5)$ & $13(26.5)$ & $2(8.3)$ & + \\
\hline Stage 分類 $(I+I I)$ & $27(36.9)$ & $9(18.4)$ & $18(75.0)$ & HI \\
\hline 細胞の配列（充実型） & $32(43.8)$ & $24(48.9)$ & $8(33.3)$ & \\
\hline 細胞型（末分化型） & $8(10.9)$ & $6(12.2)$ & $2(8.3)$ & \\
\hline 出血巣のあるもの & $48(65.8)$ & $30(61.2)$ & $18(75.0)$ & \\
\hline 壊死巣のないもの & $40(54.8)$ & $24(48.9)$ & $16(66.7)$ & \\
\hline
\end{tabular}

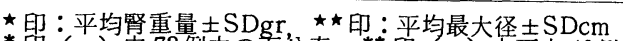

印 ( ) 内 73 例中の宣分率 **印( $)$ 内死亡 49 例中の 百分率, ***印 ( ) 内生存 24 例中の面分率 


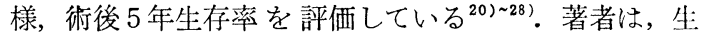
存率曲線を推計学的に検討した結果, 術後 5 年生存率の 評価で，充分妥当であると考兄た。

生存率の単純な比較は，対称群の構成，あるいは，生

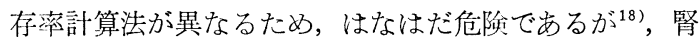
剔出例 5 年生存率は, $40 \%$ 前後 ${ }^{2729}$ と久なされ, 著者の 成績も同程度であつた，最も良い治療成績は Radical nephrectomy 施行した $66.3 \%{ }^{30)}$ であるが，悪性度の低い 症例を多く含む対象のためと批判されている ${ }^{311}$.

1）患者側因子と予後

本腫瘍の発症年秢は, 近年, 若年化傾向を示し，40歳 台に増加しているという ${ }^{32}$. 著者は他の報告 ${ }^{24) 25(33)}$ にも みられる若年女子好発傾向をみとめたが，多数例を集計 した欧米文献 ${ }^{934}$ にはみられない，本腫瘍は，他の悪性 腫瘍の予後に反して, 若年者の予後良好と理解されてい る ${ }^{35}$ が，実際には，差はないと考えられた。

本腫湯の性差は著しく, 男女比 2 対 ${ }^{36)}$, あるいは, 3.5 対 $1^{19)}$ といわれる.ここでは，2 対 1 であつた. 女子 の予後良好 ${ }^{25)}$ ，要いい，不良 ${ }^{35)}$ とするもの等がある が，実際には，差はない之考兄て良いであるら，発生に 著しい性差があり ${ }^{16)}$, 本腫瘍に罹患した妊婦は極めて子 後良好で3738), 前立腺癌のエストロゲン治療中の腎腫瘍 発症が注目され ${ }^{39}$, また，自然退縮例が男子に多発して いる ${ }^{15)}$ 等, 性と年齿 との特異な関連性が論じられる点 は, 本腫場の一つの特徴である.

初発症状発現から来院までの期間と予後については, 早期来院例活ど予後良好 ${ }^{35}$ といわれ，著者もその傾向を みとめたが，早期来院例かならずしも低進展度例とはい えず25), 重要な因子とは考光られない。

侐氺のみを主症状と与るものの予後良好 ${ }^{35}$ は著者の椮 討で, 推計学的に極めて有意であつた，從つて，迈尿を 主訴とした患者の積極的な検索が必要と考兄られる. し かし，木腫痬で血尿を呈した患者の中，42\%は他の泌㽷 器疾患と彮断されていた程, 早期診断乞のものにも問 題は多い40). 従つて, 承路外症状を初発とする本症に

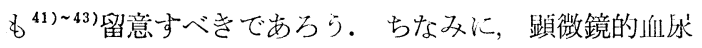
もみない腫瘍は $23 \sim 44 \%{ }^{35}$ (44)に㐫り，著者も同頻度にこ れをみとめ，こ水らの予後は不良で频つた。

腎部疼痛，腎部腫瘤，および，るいそう等の全身症状 をみとめるものの予後は不良であつたが，Ochsner ${ }^{45)} の$ 成績よりも良好であつた。古典的三主徴を具備するもの

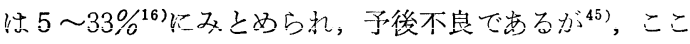
では，わずか 3 例 (2.9\%) にみられたのみで，検討し
得なかつた。

発熱は，2.8～68\% ${ }^{23) 46)}$ にみとめられ，血尿，腎部 悀，拈よび，発熱の三主徴とすべきだと主張される 程 ${ }^{47}$, 重要な徵候とされる. その原因として, 出血, 壊 死, 感染, あるいは, 組織型との関連性が強く示唆 ${ }^{48) 49}$ され，腫瘍組織から分泌される発熱物質子考兄られてい $る^{46) 50)}$ ．予後との関連性は，これを否定するものも ${ }^{25) 48}$ あるが，多くは予後不良としている ${ }^{23)}$. 著者の成績は， 組織型との関連性を認めず，比較的有意に予後不良であ つた。 また，発熱例26例中25例 $(96.2 \%)$ は赤沈元進例 で，有意の関連性を示したことから，赤沈充進，および 発熱を惹起するものは，両者に何らかの関連性を有する 物質と考えられた。

赤沈值元進は， $75.3 \%$ にみとめるものもあり ${ }^{41)}$, 予 後評価因子の一つとされる程 ${ }^{28) 51552}$, 重要な徵候之考克 られている. 赤沈元進は, 腫瘍からの産生物質によると 推測されて扮り，血清グロブリン ${ }^{23)}$ ，西るいは，血清フ ィブリノーゲン ${ }^{53}$ 等の関与も考学られる. また，組織学 的悪性度 ${ }^{8}$ や細胞型 ${ }^{48)}$ との関連性も指摘されている. 著 者の検討では，大きくて重い腫瘍，あるいは，未分化型 のものが，有意に赤沈艺進して抢り，発熱例が有意に多 かつた．赤沈充進例の予後は不良 ${ }^{23) 27228)}$ である. 実際, 著者の成績も，予後不良であつたが，最も適当な予後評 価因子とはいえなかつた。

貧血も，Bowman の三主微 ${ }^{54}$ とあげられる程，重要 な徵候と考えられている．腫瘍組織からの産生物質が貧

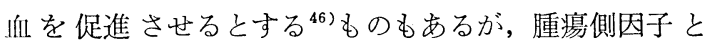
の関連性をみとめないものも ${ }^{55}$ あり, 詳細不明である. 16〜88\% 亿 $^{16,56)}$ みられるといらが，著者の成績は $27.5 \%$ であつた．貧血例の予後は不良とされて ${ }^{20,27,35)}$ 特り，実 際，著者の成績む同様の傾向を示したが，予後との関連 性は認めなかつた。

以上, 患者側因子のうち，予後評価因子としてあげら 机るのは, 発熱よりも赤沈值 ${ }^{28)}$, あるいは, 発熱, 赤沈 值，CRP，血清蛋白分画異常等 ${ }^{23)}$ であるが，著者の成績 では，血尿のみ，赤沈值，扣よび，発熱等の因子が，予 後評価因子として良いと考えられた。

2）腫瘍側因子と予後

患側については，右側腫瘍は診断容易で予後良好 ${ }^{35)}$ と いうものもあるが，多くは予後との関連性をみとめな い. 実際，著者の成績も右側腫瘍は䛦断容易で，リンパ 節転移は有意に左側に多発したので，右側腫場の予後良 好とみられた。しかし，予後不良である血尿をみないも 
のが有意に右側にみられたことが，予後との関連性をみ なかつた要因の一つであろう.

腎重量と予後については, いずれの報告も重いもの程 予後不良として ${ }^{20) 25) 2735)}$ (る. 著者の成績も同様で, 重 いもの程, 有意に予後不良であつた.

腫瘍の大ささについて， $5 \mathrm{~cm}$ 以下 $^{57) ， あ る い は ， 6.8 ~}$ $\mathrm{cm}$ 以下 ${ }^{58)}$ のものは転移が少なく, 腎径と腫瘍径との比 が大なるもの程，死亡率が高( ${ }^{59)}$ と指摘されている. 従つて, 大きな腫瘍程, 予後不良とされ, $7 \mathrm{~cm}$ 以上は

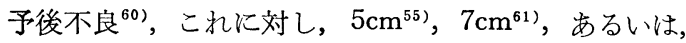
$8 \mathrm{~cm}$ 以下 ${ }^{62}$ は予後良好といわれている. 確かに, 著者 の成績も $7 \mathrm{~cm}$ を超える大きな腫瘍の予後は不良であつ たが，腫瘍の大きさと予後との関連性はみとめなかつ た。

腫瘍被膜は，本腫瘍に特有な腫瘍塊を囲繞する線維性 被膜で，予後に影響を与える因子の一つ之評価されてい $る^{63)}$. その存在は，予後良好年1)63(64)(われ，実際，著 者の成績も同様で，比較的有効な予後評価因子の一つで あつた，すなわち，被膜形成のない腫瘍は，充実型特に 未分化型に多く，被膜形成は局所進展傾向を抑制する方 向に作用するか, あるいは，発育速度の遅い腫瘍にみら れるものと考えられた。

腎需内侵潤例 の予後は不良である ${ }^{61)}$. 著者の成績も 同様であつた。静脈栓塞例，あるいは，リンパ節転移例 と，有意に関連をみたことに影響されたと考えられる。 予後評価に有効な因子の一つであつた.

静脈内腫瘍栓塞例の予後も不良 ${ }^{21) 24) 25) 27) 35) 65) て ゙ あ る . ~}$ すなわち，腎重量との関連をみとめ ${ }^{66)}$ ，腎周囲の静脈怒 張が著しいといら ${ }^{67)}$. これに対し，女子の腫瘍栓塞例は 術後 2 年まで有意に尒後良好 ${ }^{68)}$ ，あるいは，細胞学的悪 性度の方が有意に予後と関連する等 ${ }^{69) 70)}$ の成績がある. 著者の成績は，性あるいは腎重量との関連をみとめず， 乳頭状あるいは腫瘍被膜形成例に，有意に少なかった。 相対生存率の検討では有意差をみなかったが，予後評価 に有効な因子の一つであつた．血管内腫瘍栓塞の鏡検的 判定については, 有用とするものと ${ }^{71)}$, 再現性に疑問を 呈するも ${ }^{72)}$ のがあり, 著者は, これを因子としなかつ た.

リンパ節転移をみとめるものの予後は不良である 30). $6.5 \mathrm{~cm}$ 以下の腫瘍はリンパ節転移をみとめず，左 右差は12対 9 といらが ${ }^{73)}$ ，著者の成績は，リンパ節転移 例の $88.2 \%$ は左側で左右差をみとめ，女性に少なく， $7 \mathrm{~cm}$ 以下の腫瘍では $29.4 \%$ レンパ節転移をみた。
た，腎重量 $300 \mathrm{~g}$ 以下のものにはリンパ節転移をみなか つた.リンパ節転移は, 比較的重要な予後評価因子の一 つと考えられた。

病期分類は, 多くの報告が予後と関連するとしてい る $^{26) 74)}$. 代表的病期分類として, Flocks と Kadesky ${ }^{75)}$, Petkovic $^{63) 64)}, \operatorname{Cox}^{76)}$ らのものがあり, 近年, TNM 分類 のP分類が有用と主張されている. ${ }^{25 ~ 27) ~}$ 著者は Holland による Robson 改変分類 ${ }^{6}$ を基準とした. その結果, 病 期分類と予後は有意の関連性を示し, 予後評価因子とし て極めて重要であると考えられた。

組織学的悪性度の分類は, 種々，おこなわれ，それら が予後と関連するといら報告も多い. ${ }^{20) 69) 78 ~ 80)}$ 細胞の 組織学的構築 ${ }^{9}$ や病期 と細胞学的悪性度との関連等 ${ }^{26) 81}$ とで予後を推測しようとするものもある。しかし，これ ら組織像は一つの腫瘍内に種々の割合で混在するので, 予後の決定には限られた有効性を認めるにすぎないとい $\zeta^{77)}$. 実際, 著者の成績は, 乳頭状のものは予後良好, 未分化型の多くは 1 年以内に死亡し, Skinner ${ }^{74}$ の示す 如く予後不良であつたが，推計学的有意差を示すには至 らなかつた。この他，間質反応执よび発育形式について 論じるものもある ${ }^{82)}$.

3）治療法と予後

腎細胞癌の治療法は，手術，放射線療法，および，化 学療法等, その選択の組み合わせは35種に特よび，一つ の選択はさらに30〜40種の組み合わせが考えられる程, 多岐にわたる ${ }^{83)}$. また，対称の構成は施設毎に異なり， 同じ悪性度あるいは病期でも，その段階は厳密には同一 でないし ${ }^{18) 31)}$ ，推計学的に検討し得る充分な症例数を得 るのは一施設では難しい ${ }^{84)}$. 従つて, 治療法の評価は,

極めて注意深い配慮が必要といえよう。

男子の手術例に自然退縮が多いことから ${ }^{15)}$ ，転移例に も積極的に腎剔出術が行われる，骨転移例における腎剔 出術の効果 ${ }^{86) 87)}$, あるいは, 積極的な補助療法が予後を 改善させる等の ${ }^{8889}$ ) 報告もある. しかし, 著者の成積 は, Middleton ${ }^{85)}$ 同様，一例の退縮例もなく，転移例に 対する手術成績は極めて予後不良といえよう.

手術法については, 根治手術の成績が優れている ${ }^{30) 90) . ~}$ しかし, Robson ${ }^{30)}$ の対象には Low grade の腫瘍が多い との批判もあり ${ }^{31)}$ ，また，手術術式の差は予後に影響を 与えない ${ }^{91)}$ と指摘される. 著者の成績は，経腹腔式の方 が，腰部斜切開法より優れていたが，本法の多くは，近 年の症例に行なわれ, 最近の術後管理の進歩が予後に影 響を与えたとも考えられる。 
補助療法のらち, 放射線療法は有効とするものが多い

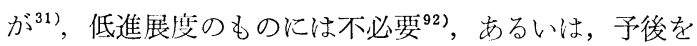
覀化せしめたとするものもある ${ }^{31151)}$ ，墨化せしめた原因 の 1 つして，右側腫瘍に対する術後照射が惹起した肝 障害が指摘されている ${ }^{93)}$. しかし，著者の検討では， Finney ${ }^{93)}$ の照射野より狭く, 左側に比し照射線量も有 意に少なく, 肝障害も無く，癌死を認めたことから，著 者のみとめた右側腎腫瘍の予後不良は，むしろ，過小 治療の傾向によるものと考えられた. 術前照射について

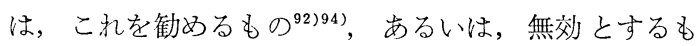
の ${ }^{95}$ がある。

化学療法については, 現在のところ, CCNU の他 ${ }^{96)}$, みるべきものはない ${ }^{97}{ }^{98}$. 持続動脈注入法等の効果 ${ }^{99) 100)}$ は，本法が全く望みのない治療法とはいえないことを示 している. 著者の成績も，何らかの化学療法を併用した 方が予後良好の傾向を示した.

ホルモン療法については，多くの報告がその有効性を 主張 ${ }^{31) 101 ~ 103)}$ している. しかし，その効果を疑問視す るものもある ${ }^{104)}$. 近年, 酢酸メドロキシプロゲステロ ンは, 腫瘍細胞の成長を直接阻害するのではなく ${ }^{105)}$, glucocorticoid receptor との結合が契機となつて, 腫痬 が維小するのではないかと墔測されている. 実際, 著者の成績は, 高進展度群に打いて, 本法の有効な傾向 をみとめたが，最近の症例に奏施されているので，断定 できない。

以上，治療法の評価について述べたが，いずれの対称 群も比較的症例数が少なく，ある傾向を示したに留ま る.また，ここに述べた治療法の他，近年，腎動脈塞栓 術，市いい，凭疫療法等が種々の形で実施されている が，まだ，評価し得る時期に至つていない。

\section{結 語}

1. 留剔出術を施行した104例を集計し，その臨床像，

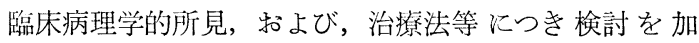
え,これら各要因と予後との關連性につき解析した。

2. 治癒判定時期は, 推計学的に術後 5 年と考兄られ た.

3. 予後と最も良く関連性を示した要因は病期分類で あつた. 比較的良く関連性を示した要因は，静脈内腫湯 栓塞，腎盂内侵潤，血尿のみ，腎重量，発熱，および， 赤沈值等であつた.

4. 治療法と予後についての関連性は, 症例数が足ら ず，充分な検討はできなかつた，乙かし，何らかの補勋 療法、を併用した方が治療成績を向上させると考えられ
た。また，経腹腔式腎剔出術，および，ホルモン療法の 併用等の治療成績が優れている傾向を示したが，これら は, 近年の術後管理の発達が影響を与をた結果とも考克 られた。

稿を終わるにあたり，御校閲戴いた恩師島崎淳教授に 深甚なる謝意を表します。また，病理所見につき御指導 戴いた本学第一病理学教室 長尾孝一講師, 同松笴理先 生, 資料の提供解析等に御協力戴いた, 国立千葉病院泌 尿器科石川堯夫部長, 国保旭中央病院泌尿器科村上 信乃部長, 同藤田道夫先生, ならびに, 教室員諸见に, 厚く御礼申し上げます。

\section{文献}

1) 栗原 登, 高野 昭：癌の治癒率の計算方法に ついて一 相対生存率 (Relative Survival rate) の意義と算出法一. 癌の臨床, 11, 628-632, 1965.

2) Cutler, S.J. and Ederer, F.: Maximum utilization of the life table method in analyzing survival. J. Chron. Dis., 8, 699-712, 1958.

3) 厚生統計協会編集 - 発行：厚生の指標, 臨時増 刊，国民衛生の動向，統計表，簡易生命表，昭 和35年～昭和 52 年.

4) 厚生省大臣宫房統計情報部編集，厚生統部協会 発行：第14回生命表，付録 II . 䌪易生命表, p. 91 - 171 ，昭和 54 年.

5) Hansen, J.B. and Thybo, E.: Long-term survival after nephrectomy for adenocarcinoma renis. Scand. J. Urol. Nephrol., 6, 47-50, 1972.

6) Holland, J.M.: Cancer of the KidneyNatural history and staging. Cancer, 32, $1030 \quad 1042,1973$.

7) Böttiger, L.E., Blank, C. and von Schreeb, 'T.: Renal carcinoma, an attempt to correlate symptoms and findings with the histopathologic picture. Acta Medica Scandinavica., 180, $329-338,1966$.

8) Claes, G.: Concerning the relationship between the morphology and the Symptomatology of hypernephroma. Urol. Int., 15, 265279, 1963.

9) Riches, E.W., Griffiths, I.H. and Thachray, A.C.: New growths of the kidney and ureter. Brit. J. Urol., 23, 297-356, 1951.

10) Arner, O. and von Shreeb, T.: Renal adenocarcinoma, prognosis. Acta Chir. Scand., 132, 370-376, 1966.

11) Ekelund, L. and Tonsson, K.: Growth rate of renai carcinoma as demonstrated by repeat angiography. Acta Radiol., 17, 786-796, 1976. 
12) Takáts, L.J. and Csapó, Z.: Death from renal carcinoma 37 years after its original recognition. Cancer, 19, 1172-1176, 1966.

13) Middleton, R.G.: Surgery for metastatic renal cell carcinoma. J. Urol., 97, 973-977, 1967.

14) Bradham, R.R., Wannamaker, C.C. and PrattThomas, H.R.: Renal cell carcinoma metastases 25 years after nephrectomy. JAMA, 223, 921-922, 1973.

15) Freed, S.Z., Halperin, J.P. and Gordon, M.: Idiopathic regression of metastases from renal cell carcinoma. J. Urol., 118, 538-542, 1977.

16) Patel, N.P. and Lavengood, R.W.: Renal cell carcinoma, natural history and results of treatment. J. Urol., 119, 722-726, 1978.

17) von Schreeb, T.: Renal adenocarcinoma. Acta Chir. Scand., Suppl. 381, 7-24, 1967.

18) 草間 悟: 癌の術後生存率とそれをめぐる諸問 題. 医学のあゆみ, 90, 187-196, 1974.

19) Ochsner, M.G., Brannan, W., Pond, H.S. III. and Goodier, E.H.: Renal cell carcinoma, review of 26 years of experience at the Oschsner clinic. J. Urol., 110, 643-646, 1973.

20) 柿崎 勉: 腎腫瘍の臨㦿的並びに病理組織学的 研究. 日泌尿会誌，48，245-268，1957.

21）宮川美栄子，吉田 修，加藤篤二：腎癌に関す る臨床統計的観察—組織像と予後を中心として 一. 泌尿紀要, 15, 304-320，1969.

22) 本間昭雄, 田宮高宏 : 腎癌 (Grawitz's 腫瘍)の 予後に関する臨床統計的観察。癌の 臨床, 15, 469-473, 1969.

23）里見佳昭：腎癌の予後に関する臨床的研究一特 に生体側の因子を中心に一。 日泌尿会誌，64， 195-216, 1973.

24）南武, 増田富士男, 佐々木忠正 : 腎細胞癌 の臨床的研究. 日泌尿会誌，66, 474- 484, 1975.

25）松田 稔, 長船匡男, 古武敏彦, 園田孝夫 : 腎 細胞癌の臨床的研究. 日泌尿会誌, 67, 635646, 1976.

26）米沢 傑, 加治木邦彦, 坂江清弘 : 腎細胞癌 の臨床病理学的検討一浸潤度, 組織学的悪性度 と予後との 関係について一. 癌の臨床, 23, 1233-1238, 1977.

27）高安久雄, 小川秋実, 上野 精, 岸 洋一, 東 原英二: 腎尿管腫瘍の治療成績. 日泌尿会誌, 69, 417-425, 1978.

28) Böttiger, L.E.: Prognosis in renal carcinoma. Cancer, 26, 780--787, 1970.

29）高安久雄, 上野 精: 腎腫瘍一診療に有用な数 值表一。 日本臨床，32，970-980，1974.

30) Robson, C.J.: Radical nephrectomy for renal cell carcinoma. J. Urol., 89, 37-42, 1963.

31) Bloom, H.J.G.: Adjuvant therapy for ad- enocarcinoma of the kidney, present position and prospects. Brit. J. Urol., 45, 237-257, 1973.

32) Nororha, R.F.X., Johnson, D.E., Guinee, V.F. and Borlase, B.C.: Changing patterns in age distribution of renal carcinoma patients. Urology, 13, 12-13, 1979.

33) 大越正秋, 長谷川昭: 腎腺癌の臨床病理学的統 計。日泌尿会誌，59，1105-1116，1968。

34) Bennington, J.L.: Cancer of the kidneyetiology, epidemiology and pathology. Cancer, 32, 1017-1029, 1973.

35) Grabstald, H.: Renal cell cancer. Part I: Incidence, etiology, natural history, and prognosis. New York J. Med., 64, 2539-2545, 1964.

36) Bennington, J.L. and Kradjian, R.M.: Renal carcinoma, p. 36-37, Saunders Co., Philadelphia, 1967.

37) Anderson, M.F. and Atkinson, D.W.: Renal carcinoma in pregnancy. Brit. J. Urol., 45, $270-272,1973$.

38) Grabstald, H.: Renal cell cancer, Part II: Diagnostic findings. New York J. Med., 64, 2658-2671, 1964.

39) Nissenkom, I., Servadio, C. and Avidor, I.: Oestrogen-Induced renal carcinoma. Brit. J. Urol., 51, 6-9, 1979.

40) Arner, O. and von Schreeb, T.: Renal adenocarcinoma, symptoms and signs. Acta Chir. Scand., 132, 348-355, 1966.

41) Melicow, M.M. and Uson, A.C.: Non urologic symptoms in patients with renal cancer. JAMA, 172, 146-151, 1960.

42) Warren, M.M., Kelalis, P.P. and Utz, D.C.: The changing concept of hypernephroma. J. Urol., 104, 376-379, 1970.

43) 増田富士男, 佐々木忠正, 高橋宣久, 荒井由 和, 南 武：腎細胞癌の尿路外症候. 泌尿紀 要, 21, 595-603, 1975.

44) Berger, L. and Sinkoff, M.W.: Systemic manifestations of hypernephroma, a review of 273 cases. Amer. J. Med., 22, 791-796, 1957.

45) Ochsner, M.G.: Renal cell carcinoma: Five year follow-up study of 70 cases. J. Urol., 93, 361-363, 1965.

46) 大越正秋, 生龟芳雄, 藤村 伸, 工藤三郎 : 腎 腫瘍の全身症状. 日泌尿会誌，56，518-536， 1965.

47) Böttiger, L.E.: Fever of unknown origin, IV., Fever in carcinoma of the kidney. Acta Med. Scand., 156, 477-485, 1957.

48) Böttiger, L.E. and Ivemark, B.I.: The structure of renal carcinoma correlated to its clinical behavior. J. Urol., 81, 512-514, 1959. 
49) Murphy, G.P. and Fishbein, R.H.: Clinical manifestation and cytology of hypernephromas. J. Urol., 85, 483—487, 1961.

50) Rawlins, M.D., Luft, R.H. and Cranston, W.I.: Pyrexia in renal carcinoma. Lancet, $\mathbf{i}$, 1371-1373, 1970.

51）阿曾佳郎, 小磯謙吉, 岡田清己, 星野嘉伸, 村 橋愁：予後からみた腎癌手術と化学療法および 放射線療法併用の評価。日泌尿会誌，65,209217，1974.

52）黑田恭一, 勝見哲郎：腎癌の化学療法, 特集尿 路性器癌の 化学療法. 臨泌, 31, 115- 122, 1977.

53) Sufrin, G., Mink, I., Fitzpatrick, J., Moore, R. and Murphy, G.P.: Coagulation factors in renal adenocarcinoma. J. Urol., 119, 727730, 1978.

54) Bowman, H.S. and Marfinez, E.J.: Fever, Anemia, and Hyperhaptoglobulinemia. Annals. Int. Med., 68, 613-620, 1968.

55) Kay, S.: Renal carcinoma. Am. J. Clin. Pathol., 50, 428-432, 1968.

56) Chisholm, G.D. and Roy, R.R.: The systemic effects of malignant renal tumors. Brit. J. Urol., 43, 687-700, 1971.

57) Bell, E.T.: A classification of renal tumors with observations on the frequency of various types. J. Urol., 39, 238-243, 1938.

58) Angervall, L., Carlström, E., Wahlquist, L. and Åhrén, Ch.: Effects of clinical and morphological variables on spread of renal carcinoma in an operative series. Scand. J. Urol. Nephrol., 3, 134-140, 1969.

59) Rafla, S.: Renal cell carcinoma-natural history and results of treatment. Cancer, 25, 26-40, 1970.

60) Dormieux, J., Crunenwald, J.M., Vetter, J.M. and Roos, M.: Réflexions sur le pronostic du cancer du rein. J. Urol. Néphrol., 80, 90-114, 1973.

61) Arner, O., Blank, C. and von Schreeb, T.: Renal adenocarcinoma, morphorogy-grading of malignancy-prognosis: A study of 197 cases. Acta Chir. Scand., Suppl. 345, 12-51, 1965.

62) Thompson, I.M., Shannon, H., Ross, G. Jr. and Montie, J.: An analysis of factors affecting survival in 150 patients with renal carcinoma. J. Urol., 114, 694-696, 1975.

63) Petkovic, S.D.: An anatomical classification of renal tumours in the adult as a basis for prognosis. J. Urol., 81, 618-623, 1959.

64) Petkovic, S.: The staging of renal parenchymal tumours. Brit. J. Urol., 47, 13-16, 1975.

65) Clarke, B.G. and Goode, W.J. Jr.: Fever and anemia in renal cancer. New Engl. J. Med., 254, 107-110, 1956.

66) McDonald, J.R. and Priestley, J.J.: Malignant tumors of the Kidney, surgical and prognostic significance of tumor thrombosis of the renal vein. Surg. Gynec. Obstet., 77, 295-306, 1943.

67) Beare, J.B. and McDonald, J.R.: Involvement of the renal capsule in surgically removed hypernephroma, a gross and histopathologic study. J. Urol., 61, 857-861, 1949.

68) Myers, G.H. Jr., Fehrenbaker, L.G. and Kelalis, P.P.: Prognostic significance of Renal vein invasion by hyperhephroma. J. Urol., 100, 420—423, 1968.

69) Skinner, D.G., Colvin, R.B., Vermillion, C.D., Pfister, R.C. and Leadbether, W.F.: Diagnosis and management of renal cell carcinomaa clinical and pathological study of 309 cases. Cancer, 28, 1165-1177, 1971.

70) Boxer, R.J., Waisman, J., Lieber, M.M., Mampaso, F.M. and Skinner, D.G.: Renal carcinoma, computer analysis of 96 patients treated by nephrectomy. J. Urol., 122, 598$601,1979$.

71) 斉藤 博, 加藤幹雄, 山内昭正, 石渡大介, 横 川正之, 青木 望, 高浜素秀: 腎腺癌の静脈内 腫湯栓塞と遠隔転移。日泌尿会誌, 70, 10721077, 1979.

72) Amtrup, F., Hansen, J.B. and Thybo, E.: Prognosis in renal carcinoma evaluated from histological criteria. Scand. J. Urol. Nephrol., 8, 198-202, 1974.

73) Hultén, L., Rosencrantz, M., Seeman, T., Wahlqvist, L. and Åhrén, Ch.: Occurrence and localization of lymphnode metastases in renal carcinoma. Scand. J. Urol. Nephrol., 3, 129-133, 1969.

74) Skinner, D.G., Vermillion, C.D. and Colvin, R.B.: The surgical management of renal cell carcinoma. J. Urol., 107, 705-710, 1972.

75) Flocks, R.H. and Kadesky, M.C.: Malignant neoplasms of the kidney: An analysis of 353 patients followed five years more. J. Urol., 79, 196-201, 1958.

76) Cox, C.E., Lacy, S.S., Montgomery, W.G. and Boyce, W.H.: Renal adenocarcinoma, 28 year review, with emphasis on rationale and feasibility of preoperative radiotherapy. J. Urol., 104, 53-61, 1970.

77) Mostofi, F.K.: Pathology and spread of renal cell carcinoma, in Renal Neoplasia edited by J. Stanton King, Jr., p. 41-85. Little, Brown and Company, Boston, 1967.

78) Syrjänen, K. and Hjelt, L.: Ultrastructural 
characteristics of human renal cell carcinoma in relation to the light microscopic grading. Scand. J. Urol. Nephrol., 12, 57-65, 1978.

79) Hand, J.R. and Broders, A.C.: Carcinoma of the kidney, the degree of malignancy in relation to factors bearing on prognosis. J. Urol., 28, 199-216, 1932.

80) Syrjänen, K. and Hjelt, L.: Grading of human renal adenocarcinoma. Scand. J. Urol. Nephrol., 12, 49-55, 1978.

81) Hermane, K.P., Sigel, A. and Chlepas, S.: Combined staging and grading of renal cell carcinoma. Z. Krebsforsch., 87, 193-196, 1976.

82）松田 稔, 長船匡男, 古武敏彦, 園田孝夫 : 腎 細胞癌, 発育形式およびリンパ球侵潤の臨床的 意義について，日泌尿会誌，67，1064-1069， 1976.

83) Rubin, P.: Current concepts in genitourinary oncology, a multi disciplinary approach. J. Urol., 106, 315-338, 1971.

84) 小暧浩司：生存率算出法の 現状とその問題点. 泌尿紀要，24，235-244，1978.

85) Middleton, R.G.: The value of surgery in metastatic renal cell carcinoma, in Renal Neoplasia, edited by J. Stanton King, Jr., p. 483-497, Little, Brown and Company, Boston, 1967.

86) Johnson, D.E., Kaesler, K.E. and Samuels, M.L.: Is nephrectomy justified in patients with metastatic renal carcinoma J. Urol., 114, 27-29, 1975.

87) Montie, J.E., Stewart, B.H., Straffon, R.A., Banowsky, L.H.W., Hewitt, C.B. and Montagne, D.K.: The role of adjunctive nephrectomy in patients with metastatic renal cell carcinoma. J. Urol., 117, 272-275, 1977.

88) Murphy, G.P., Moore, R.H. and Kenny, G.M.: Current results from primary and secondary treatment of renal cell carcinoma. J. Urol., 104, 523-527, 1970.

89）岡直友, 長谷川辰寿: 転移からみた腎癌の臨 床成績について. 日泌尿会誌，59，311-322， 1968.

90) Whitmore, W.F. and Krause, C.: Survival following nephrectomy for renal cell cancer, in Renal Neoplasia, edited by J. Stanton King, Jr., p. 447-454, Little, Brown and Company, Boston, 1967.

91）里見佳昭, 高井修道, 福島修司, 近藤猪一郎, 吉邑貞夫, 古畑哲彦, 岩崎孝史, 石塚栄一：腎 細胞癌における腎摘除術術式の相違による予後 にっいて．泌尿紀要， 26, 1-7, 1980.
92) Sir Eric Riches.: Surgery of renal carcinoma in review: Factors in survival-preoperative irradiation, in Renal Neoplasia, edited by J. Stanton King, Jr. p. 499-520, Little, Brown and Company, Boston, 1967.

93) Finney, R.: An evaluation of postoperative radiotherapy in hypernephroma treatment-a clinical trial. Cancer, 32, 1332-1340, 1973.

94) Rubin, P., Keller, B., Cox, C. and Eassa, E.H.: Preoperative irradiation in renal cancer, evaluation of radiation treatment plans. Am. J. Roentgenol., 123, 114-122, 1975.

95) van der Werf-Messing, B.: Carcinoma of the Kidney. Cancer, 32, 1056-1061, 1973.

96) Merrin, C., Mittelman, A., Famus, N., Wajsman, Z. and Murphy, G.P.: Chemotherapy of advanced renal cell carcinoma with vinblastine and CCNU. J. Urol., 113, 21-23, 1975.

97) 高井修道 : 腎癌の化学療法. 臨泌, 26, 臨時増 刊特集 5, 189-192, 1972 .

98) Lokich, J.J. and Harrison, J.H.: Renal cell carcinoma, natural history and chemotherapeutic experience. J. Urol., 114, 371-374, 1975.

99) Brendler, H., Leitev, E. and Edelman, S.: Continuous intra-arterial perfusion of kidney tumors with cytotoxic agents prior to nephrectomy, in Renal Neoplasia, edited by J. Stanton King, Jr., p. 593-603, Little, Brown and Company, Boston, 1967.

100) 増田富士男: 腎癌の抗癌剤動注療法. 臨泌, 26, 臨時增刊特集 5，193-201，1972.

101）里見佳昭, 岡本重礼: 腎癌のホルモン療法. 日 泌尿会誌，63，939-950，1972.

102）竹内弘幸：腎癌にお汀る testosterone 療法の検 討。癌の臨床, 18, 801-805, 1972.

103) 里見佳昭, 岡本重礼, 高井修道 : 腎癌肺転移の 臨床的検討。癌の臨床, 20, 397-402, 1974.

104) Alberto, P. and Senn, H.J.: Hormonal therapy of renal carcinoma alone and in association with cytostatic drugs. Cancer, 33, 1226-1229, 1974.

105) Cummings, K.B., Wheelis, R.F. and Nelson, F.W.: Role of hormones in growth kinetics of renal cell carcinoma in vitro. J. Urol., 117, 269-271, 1977.

106) Bojar, H., Maar, K. and Staib, W.: The endocrine background of human renal cell carcinoma, IV. Glucoconticoid receptors as possible mediators of progestogen action. Urol. Int., 34, $330-338,1979$.

（1980年 4 月 12 日受付） 